\title{
CALIBRATION OF A CAPACITANCE PROBE IN A PALEUDULT
}

\author{
Cláudio Ricardo da Silvaㅜ; Aderson Soares de Andrade Júnior²*; José Alves Júnior³; Antonio \\ Barros de Souza ${ }^{4}$; Francisco de Brito Melo²; Maurício Antonio Coelho Filho ${ }^{5}$ \\ ${ }^{1}$ UFPI - Campus Cinobelina Elvas - Rod. BR 135 - km 3 - 64900-000 - Bom Jesus, PI - Brasil. \\ ${ }^{2}$ Embrapa Meio-Norte, C.P. 01 - 64006-220 - Teresina, PI - Brasil. \\ ${ }^{3}$ Embrapa Arroz e Feijão, Rod. Goiânia - Nova Veneza - km 12 - Zona Rural - 75375-000 - Santo Antonio, GO - \\ Brasil. \\ ${ }_{5}^{4}$ UFPI/CCA - Graduando em Agronomia. \\ ${ }^{5}$ Embrapa Mandioca e Fruticultura Tropical, C.P. 07 - 44380-000 - Cruz das Almas, BA -Brasil. \\ *Corresponding author <aderson@cpamn.embrapa.br>
}

\begin{abstract}
The use of capacitance sensors is one of the methods used to quantitatively measure soil water contents $\left(\theta, \mathrm{m}^{3} \mathrm{~m}^{-3}\right)$. Sensors provide readings at desired depths and time intervals. A capacitance probe (Diviner 2000) was calibrated for a Rhodic Paleudult from the Piaui State, Brazil. Six access tubes were installed in a $5 \times 2 \mathrm{~m}$ grid arrangement. Three moisture levels (saturated, moist and dry) were used in two replications. Probe readings and soil samplings to determine $\theta$ were made at 0.1 $\mathrm{m}$ depth intervals down to a depth of $1.0 \mathrm{~m}$. A power calibration equation was developed for each depth as well as for the entire soil profile (Root Mean Square Error $=0.014, R^{2}=0.93$ ) for a $\theta$ range of 0.068 to $0.264 \mathrm{~m}^{3} \mathrm{~m}^{-3}$. A separate calibration for each depth improves the correlation coefficient and minimizes RMSE. Site-specific calibration improves the accuracy for soil water monitoring.
\end{abstract}

Key words: FDR probe, sensor, irrigation, soil water content

\section{CALIBRAÇÃO DE UMA SONDADE CAPACITÂNCIA EM UM ARGISSOLO}

\begin{abstract}
RESUMO: Sensores de capacitância são alternativas aos métodos comuns de quantificação do teor de água do solo $\left(\theta, \mathrm{m}^{3} \mathrm{~m}^{-3}\right)$, provendo leituras em profundidade de forma segura e rápida. Neste estudo, uma sonda de capacitância (Diviner 2000) foi calibrada em um Argissolo vermelho-amarelo do Estado do Piauí, Brasil. Seis tubos de acesso foram instalados em uma grade de $5 \mathrm{~m} \times 2 \mathrm{~m}$. Três níveis de umidade (saturado, úmido e seco) foram aplicados em duas repetições. Efetuaram-se leituras do equipamento, para cada $0.1 \mathrm{~m}$ de solo, até $1.0 \mathrm{~m}$ de profundidade, juntamente com amostras de solo para a determinação de $\theta$. Uma equação de potência foi desenvolvida para cada profundidade como também para o todo perfil do solo (RMSE $=0.014, R^{2}=0.93$ ) em um intervalo de 0.068 a $0.264 \mathrm{~m}^{3} \mathrm{~m}^{-3}$ of $\theta$. A calibração para cada profundidade melhora o coeficiente de correlação e minimiza o erro das estimativas. Calibrações locais melhoram a acurácia do monitoramento da água no solo.

Palavras-chave: sonda de FDR, sensor, irrigação, teor de água do solo.
\end{abstract}

\section{INTRODUCTION}

Irrigation control based on soil water status is one of the most useful methods of scheduling due to its practicability and low cost (Silva et al., 2005). The most common methods that have been used to measure soil water contents are the gravimetric and neutron thermalization (Gardner et al., 1991). Recently in Brazil, the capacitance method has also been used to measure soil water content.

The capacitance method includes a probe with a pair of electrodes or electrical plates that behave as a capacitor. When activated, the soil-water-air matrix works as a dielectric of capacitor and completes an oscillating circuit (Heng et al., 2002). Changes in the resonant frequency $(F)$ of the circuit depend on the changes in the capacitance, which is given by $F=$ $[2 \pi \sqrt{ }(\mathrm{LC})]^{-1}$, where $\mathrm{L}$ and $\mathrm{C}$ are circuit inductance and total capacitance, respectively (Paltineanu \& Starr, 1997). The method has several attractive features: it is safe, measurements are rapid, and can be used to automate data collection using a data logger.

Calibration of the capacitance probe has to be made carefully to estimate the soil water contents ac- 
curately. Despite of the availability of a manufacturer universal calibration, results have shown that the calibration for individual soils improves the accuracy (Paltineanu \& Starr, 1997; Baumhardt et al., 2000; Morgan et al., 1999; Leib et al., 2003; Fares et al., 2004; Groves \& Rose, 2004). However, field calibration is laborious and has to be made carefully to give yield results.

The objectives of this study were (i) to determine the field calibration equation for a capacitance probe in a Rhodic Paleudult from the Piaui State, Brazil; and (ii) to compare it to the manufacturer calibration equation.

\section{MATERIAL AND METHODS}

\section{Experimental area}

The calibration was conducted in Teresina, State of Piaui, Brazil (05 $05^{\circ}$ 'S, $42^{\circ} 48^{\prime} \mathrm{W}$ and elevation 74.4 m) from $10 / 30 / 2005$ to $12 / 20 / 2005$, which has a tropical climate with average annual air temperature and relative humidity of $27.9^{\circ} \mathrm{C}$ and $69.2 \%$, respectively, and annual rainfall of 1,299 mm (Bastos \& Andrade Júnior, 2000). There are about 1.5 million hectares of Paleudults in Piaui State. About $82 \%$ of the area has potential for pasture and agriculture, especially with irrigation (Embrapa, 1989). Table 1 shows the physical and chemical soil proprieties of the experimental area.

\section{Capacitance probe}

A capacitance probe (model Diviner 2000, Sentek Pty Ltd., Stepney South Australia) was used in this experiment. The sensor is a hand-held, portable soil moisture monitoring device consisting of a display/logger unit, connected by a cable to an automatic depth-sensing probe that is moved up and down in an access tube. During calibration, the manufacturer recommends normalizing the probe using the scaled frequency (SF) values for air and water $\left(\approx 25^{\circ} \mathrm{C}\right)$.

$S F=\left(F_{a}-F_{s}\right)\left(F_{a}-F_{w}\right)^{-1}$

where: $F_{a}$ is the $S F$ in air; $F_{s}$ is the $S F$ in soil; $F_{w}$ is the $S F$ in water.
The normalization is necessary to obtain meaningful data continuously, since it is impossible to tune on all sensors to count the exact frequency when measuring a particular standard, e.g. in a container of water (Sentek, 2000). The values for $F_{a}$ and $F_{w}$ were fixed at 164919 and 121850 , respectively.

\section{Access tube installation}

Six PVC plastic access tubes were installed using a $5 \times 2 \mathrm{~m}$ spacing (Figure 1a). The installation of the tubes was made following the procedures suggested by the manufacturer (Sentek, 2000) to ensure good contact between the soil and the access tube wall. Briefly, the access tubes were driven into the soil in $\approx 0.15 \mathrm{~m}$ increments using a sledgehammer, extracting the soil inside the tubes with a $47 \mathrm{~mm}$ soil auger. This procedure reduces air gaps and variations in soil bulk density adjacent to the access tubes. Tubes were $1.5 \mathrm{~m}$ long with internal and external diameters of 51 and $56.5 \mathrm{~mm}$. After the installation, $4 \mathrm{~cm}$ of the access tubes were left above the soil surface to prevent water entrance. A plastic top cap was firmly fitted to the upper end of each access tube. After 15 days, three trenches $(3 \times 1.5 \times 1.5 \mathrm{~m})$ were excavated about 0.4 $\mathrm{m}$ away from each access tube.

As recommended by the manufacturer (Sentek, 2001), three moisture levels: saturated, moist and dry were used to cover the soil water content range at the site. Two access tubes were installed for each moisture level. For the saturated level, approximately $200 \mathrm{~L}$ of water were applied in a cylindric infiltrometer $(0.5 \mathrm{~m} \varnothing)$ so that the wetted front passed the $1.0 \mathrm{~m}$ soil depth. For the intermediate level the amount of applied water was reduced by half. Since the experiment was carried out in the end of dry period (November), no addition of water was required for the dry level.

\section{Sampling procedure and calibration}

Three scaled frequency $(S F)$ readings per tube were recorded at depth intervals of $0.1 \mathrm{~m}$, down to $1.0 \mathrm{~m}$. Immediately after the readings, a soil platform at each $0.1 \mathrm{~m}$ depth increment was made to determine

Table 1 - Selected physical and chemical properties from a Rhodic Paleudult in Teresina, Brazil (12/13/2005).

\begin{tabular}{|c|c|c|c|c|c|c|c|}
\hline \multirow{2}{*}{ Depth } & \multirow{2}{*}{ Layer } & \multicolumn{3}{|c|}{ Granulometry } & \multirow{2}{*}{$\rho^{\dagger}$} & \multirow{2}{*}{ O.M.* } & \multirow{2}{*}{ Textural class } \\
\hline & & Sand & Silt & Clay & & & \\
\hline (m) & & & $\mathrm{g} \mathrm{kg}^{-1}$ & & $\mathrm{~kg} \mathrm{~m}^{-3}$ & $\mathrm{~g} \mathrm{dm}^{-3}$ & \\
\hline $0.00-0.15$ & $A_{p}$ & 785.8 & 78.5 & 136.0 & 1.63 & 9.25 & Loamy sand \\
\hline $0.15-0.35$ & $\mathrm{~A}_{12}$ & 675.5 & 98.5 & 226.0 & 1.71 & 9.76 & Sandy clay loam \\
\hline $0.35-0.65$ & $\mathrm{Bt}_{12}$ & 606.5 & 97.5 & 296.0 & 1.54 & 6.59 & Sandy clay loam \\
\hline$>0.65$ & $\mathrm{Bt}_{21}$ & 607.5 & 126.5 & 266.0 & 1.49 & 3.64 & Sandy clay loam \\
\hline
\end{tabular}

'Soil bulk density; *Organic matter. 
the soil gravimetric water content and bulk density. Soil core samples around the tube were collected and kept in an aluminum can. To determine the bulk density, two undisturbed soil samples were carefully collected by using rings ( $52.4 \mathrm{~mm} \varnothing$ by $48.7 \mathrm{~mm}$ high) placed horizontally in such a way that the center of sampling ring was in the middle of each layer and at a distance of about $8 \mathrm{~cm}$ from the of tube (Figure 1b). Oven drying was made at $105^{\circ} \mathrm{C}$ for 48 hours. Regression analyses were conducted using $S F$ readings and their corresponding volumetric soil water content for each sampling depth as well as for the entire profile using the software TableCurve v.5.01 (SYSTAT Software Inc., San Jose, CA, USA). A t test was used to verify whether the means of estimated soil water content $(\theta)$ were different when different calibrations curves are used for the whole soil profile.

\section{RESULTS AND DISCUSSION}

The $S F$ values corresponded to the chosen soil moisture levels, i.e., 0.57 (dry), 0.65 (moist) and 0.74 (saturated), confirming that the methodology was adequate to obtain $S F$ values in a wide range of soil water contents (0.068 to $0.264 \mathrm{~m}^{3} \mathrm{~m}^{-3}$, Figure 2). The highest and lowest $S F$ values were 0.7819 (saturated, $0.3 \mathrm{~m}$ depth) and 0.4916 (dry, $0.1 \mathrm{~m}$ depth). At the $0.2 \mathrm{~m}$ depth, there was a peak in $S F$ values for all moisture levels, probably influenced by soil compaction. Because of this, an individual calibration for each soil may be more accurate (Baumhardt et al., 2000; Leib et al., 2003).
Individual calibrations per depth (Table 2) improved almost all correlation coefficients and minimized the Root Mean Square Error (RMSE) when compared to a unique calibration for the entire profile $(0-1.0 \mathrm{~m})$. Exceptions were at 0.9 and $1.0 \mathrm{~m}$ depth,

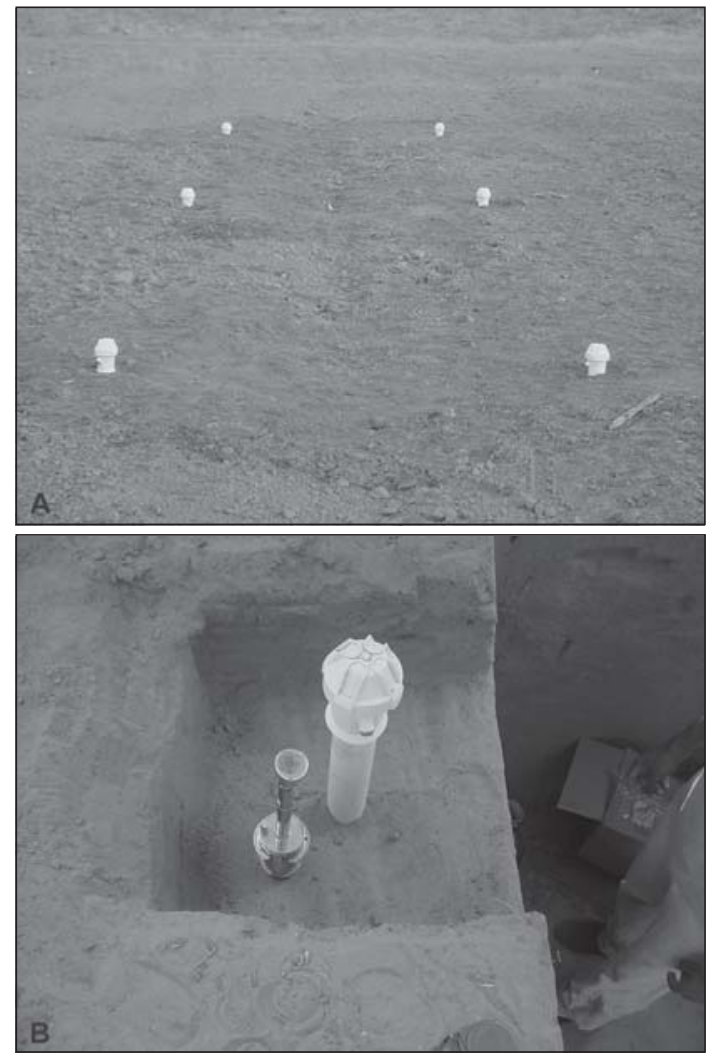

Figure 1- (a) The access tubes in a grid system $(5 \times 2 \mathrm{~m})$ and soil sample extracted from a platform to determine the soil bulk density (b).

Table 2 - Calibration equations for the capacitance probe for different soil layers using a power model.

\begin{tabular}{|c|c|c|c|c|c|c|c|}
\hline \multirow{2}{*}{ Horizon } & \multirow{2}{*}{$a^{\dagger}$} & \multirow{2}{*}{$b$} & \multirow{2}{*}{$R^{2}$} & \multirow{2}{*}{ RMSE* } & \multirow{2}{*}{$\mathrm{N}$} & \multicolumn{2}{|c|}{ Soil water content range } \\
\hline & & & & & & Low & High \\
\hline $\mathrm{m}$ & & & & & & \multicolumn{2}{|c|}{$-\cdots$} \\
\hline $0.1^{\ddagger}$ & 0.742 & 3.782 & 0.98 & 0.011 & 5 & 0.067 & 0.233 \\
\hline 0.2 & 0.503 & 3.144 & 0.98 & 0.009 & 6 & 0.098 & 0.247 \\
\hline 0.3 & 0.457 & 2.553 & 0.98 & 0.009 & 6 & 0.099 & 0.264 \\
\hline 0.4 & 0.484 & 2.596 & 0.99 & 0.007 & 6 & 0.101 & 0.252 \\
\hline 0.5 & 0.506 & 2.707 & 0.93 & 0.017 & 6 & 0.104 & 0.242 \\
\hline 0.6 & 0.542 & 2.923 & 0.97 & 0.011 & 6 & 0.104 & 0.238 \\
\hline 0.7 & 0.524 & 2.923 & 0.94 & 0.014 & 6 & 0.104 & 0.221 \\
\hline 0.8 & 0.476 & 2.640 & 0.92 & 0.013 & 6 & 0.116 & 0.216 \\
\hline 0.9 & 0.527 & 3.051 & 0.90 & 0.012 & 6 & 0.116 & 0.210 \\
\hline 1.0 & 0.503 & 2.813 & 0.56 & 0.021 & 6 & 0.121 & 0.198 \\
\hline $0-1.0$ & 0.492 & 2.757 & 0.93 & 0.014 & 59 & 0.067 & 0.264 \\
\hline
\end{tabular}

${ }^{+}$The coefficients $a$ and $b$ are for the calibration $\theta=a \mathrm{SF}^{b}$, where $S F, \theta$, and $\mathrm{N}$ are the scaled frequency readings, the soil water content $\left(\mathrm{m}^{3} \mathrm{~m}^{-3}\right)$, and the number of samples used per analysis, respectively. ${ }^{\ddagger}$ One outlier data point was disregarded. ${ }^{*} \mathrm{RMSE}=\mathrm{Root}$ Mean Square Error. 
Table 3 - Data source, equations, coefficients of determination $\left(R^{2}\right)$, root mean square errors (RMSE), and the number of observations $(N)$ from different calibrations developed for capacitance probes under field conditions.

\begin{tabular}{llllc}
\hline Data source & \multicolumn{1}{c}{ Equation $^{1}$} & $R^{2}$ & RMSE & $N$ \\
\hline Manufacturer calibration & $\theta=0.494 S F^{3.017}$ & 0.99 & - & - \\
Morgan et al. (1999) & $\theta=0.451 S F^{2.121}$ & 0.83 & 0.008 & - \\
Fares et al. (2004) & $\theta=0.440 S F^{1.549}-0.040$ & 0.88 & 0.029 & 60 \\
Local calibration & $\theta=0.492 S F^{2.757}$ & 0.93 & 0.014 & 59 \\
\hline
\end{tabular}

${ }^{1}$ where $S F$ and $\theta$ are the scaled frequency readings and the estimated soil water content $\left(\mathrm{m}^{3} \mathrm{~m}^{-3}\right)$.

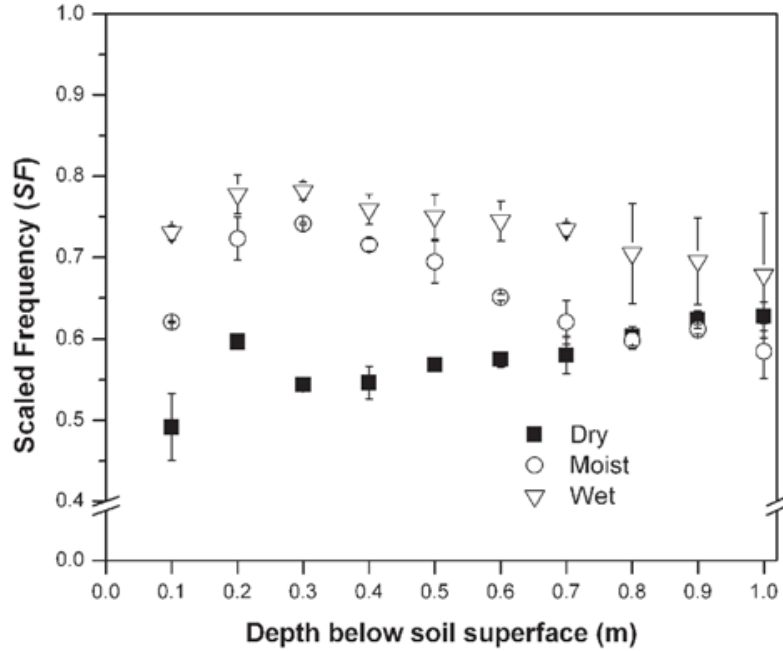

Figure 2 - Scaled Frequency (SF) through the soil profile (0.1-1.0 m) under three soil moisture levels (dry, moist, saturated). Symbols represent averages of two data points. Standard deviations around the mean are also indicated.

probably due to the low range between saturated and dry soil as well as the high $S F$ deviation observed for the saturated soil (Figure 2). However, within the 1.0 $\mathrm{m}$ soil depth, the mean estimated $(\theta)$ with individual calibration for each depth was not different $(P>0.05)$ from that of the entire soil profile $\left(\theta=0.492 S F^{2.757}\right)$.

Table 3 shows the differences between the local calibration, the manufacturer calibration and other previous field calibrations (Morgan et al., 1999; Fares et al., 2004). The power model for the local calibration had a high correlation coefficient as compared to the other field calibrations, but the RMSE was higher than that obtained by Morgan et al. (1999).

Values of $\theta$ estimated with the manufacturer calibration were not different from those estimated with the local calibration equation $(P>0.05)$ according to the t-test. The mean difference was $0.014 \mathrm{~m}^{3}$ $\mathrm{m}^{-3}$. The acceptable performance of the manufacturer calibration was, probably, because it was based on data from samples of sand and sandy loam soil textural classes, very similar to those used in this experiment.

The manufacturer calibration resulted in a 9.24\% underestimation when compared to the local

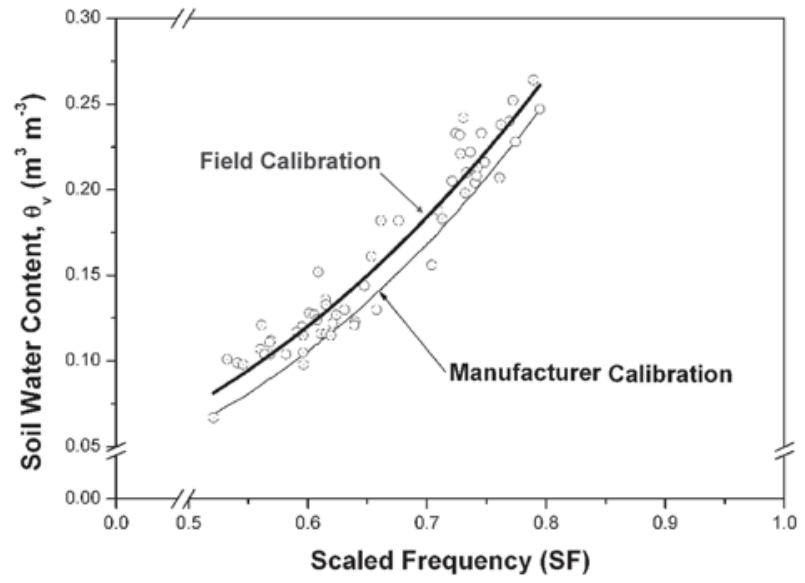

Figure 3 - Calibration of Diviner 2000 capacitance probe in a Rhodic Paleudult of the Piaui State in the 0.068 to $0.264 \mathrm{~m}^{3} \mathrm{~m}^{-3} \theta$ range and soil water trends estimated by the manufacturer calibration.

calibration (Figure 3). Despite the suitable results by the t-test and by the small mean difference, an underestimation in $\theta$ can encourage slight over-irrigation if absolute soil water content values are used. Moreover, individual calibrations for each depth in the soil profile improve correlation coefficients. Thus, site-specific calibration improves the accuracy of soil water monitoring and is recommended especially for areas in the Northeast of Brazil that have a limited water supply.

\section{ACKNOWLEDGEMENTS}

To CNPq and the Piaui Research Foundation (FAPEPI) for financial support.

\section{REFERENCES}

BASTOS, E.A.; ANDRADE JÚNIOR, A.S. Dados agrometeorológicos para o município de Teresina, PI (1980-1999). Teresina: Embrapa Meio-Norte, 2000. 25p. (Embrapa Meio-Norte. Documentos, 47).

BAUMHARDT, R.L.; LASCANO, R.J.; EVETT, S.R. Soil material, temperature, and salinity effects on calibration of multisensor capacitance probes. Soil Science Society of America Journal, v.64, p.1940-1946, 2000.

EMBRAPA. Diagnóstico e prioridades de pesquisa em agricultura irrigada: região Nordeste. Brasília: DPL, 1989. p.27-162, (Embrapa-DPL. Documentos, 9). 
FARES, A.; BUSS, P.; DALTON, M.; EL-KADI, A.I.; PARSONS, L.R. Dual field calibration of capacitance and neutron soil water sensors in a shirinking-swelling clay soil. Vadose Zone Journal, v.4, p.1390-1399, 2004.

GARDNER, C.M.K.; BELL, J.P.; COOPER, J.D; DEAN, T.J.; HODNETT, M.G.; GARDNER, N. Soil water content. In: SMITH, R.A.; MULLINGS, C.E. (Ed.) Soil analysis: physical methods. New York: Marcel Dekker, 1991. cap.1, p.1-73.

GROVES, S.J.L; ROSE, S.C.L. Calibration equations for Diviner 2000 capacitance measurements of volumetric soil water content of six soils. Soil Use and Management, v.20, p.9697, 2004

HENG, L.K.; CAYCI, G.; KUTUK, C.; ARRILLAGA, J.L.; MOUTONNET, P. Comparison of soil moisture sensors between neutron probe, Diviner 2000 and TDR under tomato crops. In: SYMPOSIUM OF TOWARDS INTEGRATED SOIL, WATER AND NUTRIENT MANAGEMENT IN CROPPING SYSTEMS: THE ROLE OF NUCLEAR TECHNIQUES, 59., Bangkok, 2002. Proceedings. Bangkok: Soil Science, 2002. (CD-ROM).

LEIB, B.G.; JABRO, J.D.; MATTHEWS, G.R. Field evaluation and performance comparation of soil moisture sensors. Soil Science, v.168, p.396-408, 2003.
MORGAN, K.T.; PARSONS, L.R.; WHEATON, T.A.; PITTS, D.J.; OBREZA, T.A. Field calibration of a capacitance water content probe in fine sand soils. Soil Science Society of America Journal, v.63, p.987-989, 1999.

PALTINEANU, I.C; STARR, J.L. Real-time soil water dynamics using multisensor capacitance probes: laboratory calibration. Soil Science Society of America Journal, v.61, p.15761585, 1997

SENTEK. Calibration of Sentek Pty Ltd soil moisture sensors. Stepney: Sentek Pty Ltd., 2001.

SENTEK. Diviner 2000: user guide version 1.21. Stepney: Sentek Pty Ltd., 2000.

SILVA, C.R.; FOLEGATTI, M.V.; SILVA, T.J.A.; ALVES JÚNIOR, J.; SOUZA, F.C.; RIBEIRO, R.V. Water relations and photosynthesis as criteria for adequate irrigation management in 'Tahiti' lime trees. Scientia Agricola, v.62, p.415-422, 2005.

Received March 22, 2006

Accepted September 03, 2007 